\title{
Borneo Journal of
}

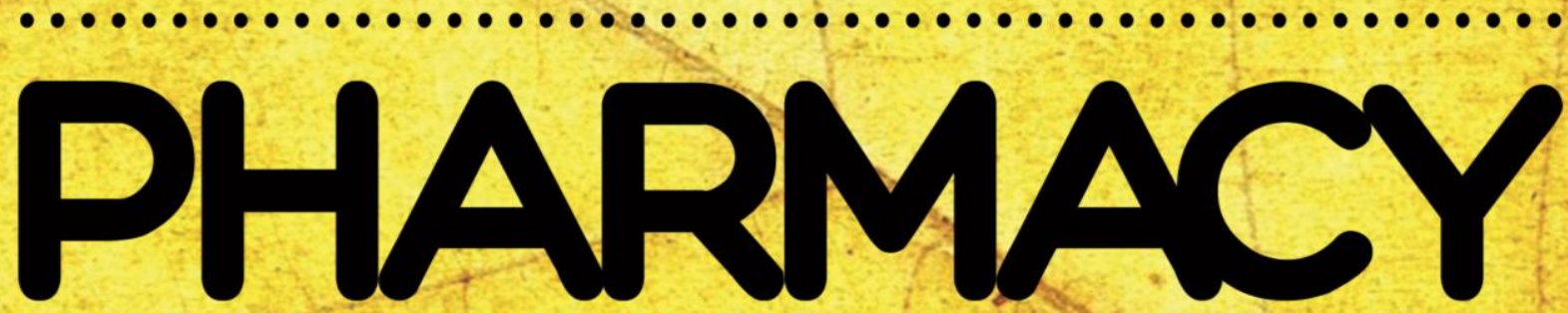

Volume 4 Issue 4 November 2021

\section{Accredited at SINTA 2 until February 2025}

by Ministry of Research and Technology / National Research and Innovation Agency, Indonesia No: $148 / M / K P T / 2020$.

Institute for Research and Community Services Universitas Muhammadiyah Palangkaraya 


\section{BORNEO JOURNAL OF PHARMACY}

Borneo J Pharm e-ISSN: 2621-4814

Volume 4 Issue 4 November 2021

Department of Pharmacy

Faculty of Health Sciences Universitas Muhammadiyah Palangkaraya

\section{EDITOR IN CHIEF}

Mohammad Rizki Fadhil Pratama

Universitas Muhammadiyah Palangkaraya, Indonesia

ORCID: http:// orcid.org/0000-0002-0727-4392

MANAGING EDITOR

Ahmed Mahal

Chinese Academy of Sciences, China

Lina Perekhoda

National University of Pharmacy, Ukraine Jyoti Singh

CSIR-CIMAP India

Shayma Thyab Gddoa Al-Sahlany University of Basrah, Iraq

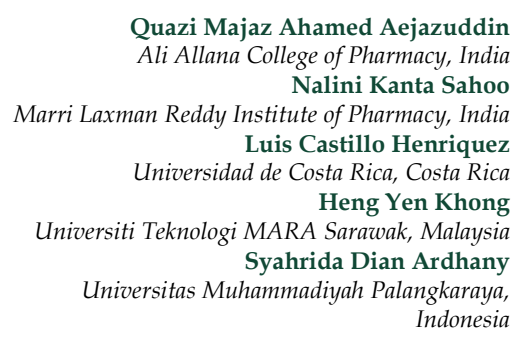

Nurolaini Kifli

Universiti Brunei Darussalam, Brunei Darussalam

Alexandru Mihai Grumezescu

Politechnica University of Bucharest, Romania

Anna Vladimirovna Kurkina

Samara State Medical University, Russia

A Lalithamma

Karpaga Vinayaga Institute of Medical Sciences, India Julaeha

Universitas 17 Agustus 1945 Jakarta, Indonesia Ihsanul Arief

Akademi Farmasi Yarsi Pontianak, Indonesia

Mohammed Gamal

Jouf University, Saudi Arabia

Dian Wuri Astuti

Sekolah Tinggi Ilmu Kesehatan Guna Bangsa

Yogyakarta, Indonesia

Monaj Kumar Sarkar

Shanmugha Arts, Science, Technology and Research Academy (SASTRA) Deemed University, India Hafsan

Universitas Islam Negeri Alauddin Makassar, Indonesia
Khalid Karrouchi Mohammed V University in Rabat, Morocco Alaa Kareem Niamah University of Basrah, Iraq Neni Frimayanti Sekolah Tingoi Ilmu Farmasi Riau, Indonesia Erwin Martinez Faller San Pedro College, Philippines Susi Novaryatiin Universitas Muhammadiyah Palangkaraya, Indonesia
Mahendran Sekar

Universiti Kuala Lumpur, Malaysia Punet Kumar

Shri Gopichand College of Pharmacy, India Rimadani Pratiwi

Universitas Padjadjaran, Indonesia Ruqiah Ganda Putri Panjaitan

Universitas Tanjungpura, Indonesia Sutomo

Universitas Lambung Mangkurat, Indonesia Arnida

Universitas Lambung Mangkurat, Indonesia Andhika Bintang Mahardhika Institut Teknologi Bandung, Indonesia

Isna Rasdianah Aziz

Universitas Islam Negeri Alauddin

Makassar, Indonesia

Dhafer Saber Zinad

University of Technology, Iraq

Paula Mariana Kustiawan

Universitas Muhammadiyah Kalimantan

Timur, Indonesia
Universitas Muhammadiyah Kalimantan

Timur, Indonesia

COVER E LAYOUT DESIGN

\section{PUBLISHED BY}

Syahrida Dian Ardhany

Institute for Research and Community Services

Universitas Muhammadiyah Palangkaraya

RTA Milono St. Km. 1,5 Palangka Raya 73111

bjop@umpr.ac.id

http://journal.umpalangkaraya.ac.id/index.php/bjop 
EDITORIAL WORDS

apt. Mohammad Rizki Fadhil Pratama, S.Farm., M.Si.

Editor in Chief

Borneo J Pharm

Assalamu'alaikum Wr. Wb.

Alhamdulillahirabbil 'alamin. The next edition of Borneo Journal of Pharmacy (Borneo J Pharm), has been published at November 2021. Starting from this volume, Borneo J Pharm increases the frequency of publishing four times a year. This change aims to improve circulation of the best articles published by Borneo J Pharm.

Starting in the 2019 edition, Borneo J Pharm has been accepted for indexing in EMBASE by Elsevier dan CAS. This is an acknowledgment of the quality of the publications presented by Borneo J Pharm. In addition, Borneo J Pharm has also been accredited at SINTA in rank 2. In the future, Borneo J Pharm will try to improve the indexing to ESCI by Web of Sciences and SCOPUS. We will ensure this achievement as a start and will continue to improve the quality of Borneo J Pharm.

This edition contains ten articles consisting of Pharmacognosy-Phytochemistry, Analytical Pharmacy-Medicinal Chemistry, Microbiology Pharmacy, Natural Product Development, and Clinical-Community Pharmacy. This edition includes writings from six countries including India, Indonesia, Nigeria, Pakistan, Sri Lanka, and Turkey. The authors come from several institutions, including University of Jaffna, Shri Gopichand College of Pharmacy, Government College University Faisalabad, Galgotias University, University of Delhi, Universitas Lambung Mangkurat, Universitas Sembilanbelas November Kolaka, Sathyabama Institute of Science and Technology, Ege Üniversitesi, Universitas Sam Ratulangi, Prathima Institute of Medical Sciences, Dr. NTR University of Health Sciences, Ganapathy Degree College, National Agency of Drug and Food Control of Republic of Indonesia, National Agency of Drug and Food Control of Republic of Indonesia in Gorontalo, National Institute for Pharmaceutical Research and Development, Universitas Jenderal Achmad Yani, and Ibrahim Adjie Health Center.

Editorial boards are fully aware that there are still room for improvement in this edition, hence with all humility willing to accept constructive suggestions and feedback for improvements to the publication for the next editions. The editorial board would like to thank all editors and reviewers, and contributors of the scientific articles who have provided the repetoire in this issue. We hope that all parties, especially the contributors, could re-participate for the publication in the next edition on February 2022.

Wassalamu'alaikum Wr. Wb.

Palangka Raya, November 2021

Editor-in-Chief 
Pharmacological screening of Eryngium foetidum Linn - A Review

Galamula Hewage Tharuka Kanchana Hemachandra / University of Jaffna

Sinnadurai Thuvaragan / University of Jaffna

Vinotha Sanmugarajah / University of Jaffna

$248-259$

Immunity-Boosting Natural Herbs to Combat COVID-19 Pandemic: A Narrative Review

Saurabh Nimesh / Shri Gopichand College of Pharmacy

Muhammad Akram / Government College University Faisalabad

Md. Iftekhar Ahmad / Shri Gopichand College of Pharmacy

Arshad Ahmad / Shri Gopichand College of Pharmacy

Pratibha Kumari / Galgotias University

Manohar Lal / University of Delhi

$260-272$

Standardization of Simplicia and Ethanol Extract of Purun Danau (Lepironia articulata (Retz.) Domin) Rhizome

Arnida / Universitas Lambung Mangkurat

Maulidia / Universitas Lambung Mangkurat

Amalia Khairunnisa / Universitas Lambung Mangkurat

Sutomo / Universitas Lambung Mangkurat

Faisal / Universitas Lambung Mangkurat

$273-282$

Chemical Constituents and Antioxidant Activity of Melothria scabra Naudin Fruits

Harni Sartika Kamaruddin / Universitas Sembilanbelas November Kolaka

Megawati / Universitas Sembilanbelas November Kolaka

Nurliana / Universitas Sembilanbelas November Kolaka

Carla Wulandari Sabandar / Universitas Sembilanbelas November Kolaka

$283-292$

Sections: ANALYTICAL PHARMACY-MEDICINAL CHEMISTRY

Traditional Turkish Coffee with Medicinal Effect Senthil Rethinam / Ege Üniversitesi E Sathyabama Institute of Science and Technology Serdar Batıkan Kavukcu / Ege Üniversitesi

Hayati Türkmen / Ege Üniversitesi Arife Candaş Adıgüzel Zengin / Ege Üniversitesi İhsan Yaşa / Ege Üniversitesi $293-300$

Correlation Analysis of Antioxidant Activities with Tannin, Total Flavonoid, and Total Phenolic Contents of Nutmeg (Myristica fragrans Houtt) Fruit Precipitated by Egg white Irma Antasionasti / Universitas Sam Ratulangi Olvie Syenni Datu / Universitas Sam Ratulangi

Utami Sasmita Lestari / Universitas Sam Ratulangi Surya Sumantri Abdullah / Universitas Sam Ratulangi Imam Jayanto / Universitas Sam Ratulangi $301-310$ 
Microbes, Clinical trials, Drug Discovery, and Vaccine Development: The Current Perspectives Venkataramana Kandi / Prathima Institute of Medical Sciences

Tarun Kumar Suvvari / Dr. NTR University of Health Sciences Sabitha Vadakedath / Prathima Institute of Medical Sciences Vikram Godishala / Ganapathy Degree College $311-323$

Use of Direct PCR Technique Without DNA Extraction in Confirmation Test for Salmonella typhimurium Bacteria on Meatball Samples

Alfi Sophian / National Agency of Drug and Food Control of Republic of Indonesia

Ratna Purwaningsih / National Agency of Drug and Food Control of Republic of Indonesia

Muindar / National Agency of Drug and Food Control of Republic of Indonesia in Gorontalo

Eka Putri Juniarti Igirisa / National Agency of Drug and Food Control of Republic of Indonesia in Gorontalo

Muhammad Luthfi Amirullah / National Agency of Drug and Food Control of Republic of Indonesia in Gorontalo $324-332$

\section{Sections: NATURAL PRODUCT DEVELOPMENT}

Compressional Physics of Binary Mixture of Dried Andrographis paniculata and Moringa oleifera

Leaves

Johnson Ajeh Isaac / National Institute for Pharmaceutical Research and Development Kokonne Elizabeth Ekere / National Institute for Pharmaceutical Research and Development Ekeh Ezekiel / National Institute for Pharmaceutical Research and Development

Isa Hayatu Galadima / National Institute for Pharmaceutical Research and Development

Rashida Abdulahi / National Institute for Pharmaceutical Research and Development Ayuba Samali / National Institute for Pharmaceutical Research and Development

\section{Sections: CLINICAL-COMMUNITY PHARMACY}

Dyspepsia Drug Use Pattern of Outpatients in a Public Health Center in Batununggal District Bandung

Linda Purnamawati Suherman / Universitas Jenderal Achmad Yani

Pudjiastuti Kartidjo / Universitas Jenderal Achmad Yani

Iis Rukmawati / Ibrahim Adjie Health Center

Vina Septiani / Universitas Jenderal Achmad Yani

Fazrin Azzura / Universitas Jenderal Achmad Yani

$345-354$ 


\title{
Author Guidelines BORNEO JOURNAL OF PHARMACY
}

\author{
Borneo J Pharm - e-ISSN: 2621-4814
}

1. Writing is the result of research or review of critical analysis study in the field but not limited to PharmacologyToxicology, Pharmacognosy-Phytochemistry, Pharmaceutical, Analytical Pharmacy-Medicinal Chemistry, Natural Product Development, Clinical-Community Pharmacy, Management Pharmacy, and other Pharmacy aspects which have never been published in other scientific publication media.

2. Manuscripts that have been published in the form of a preprint on several platforms such as arXiv, INA-RXiv, SSRN, and ResearchGate are welcome to publish.

3. The manuscript is written in English with Book Antiqua font 10 pt, two-column, density 1.15 spaces, on A4 paper with a top-down margin of $2.5 \mathrm{~cm}$ and right-left margins $1.5 \mathrm{~cm}$.

4. The manuscript is typed with MS-Word program using the provided template and saved in .doc or .docx format.

5. The manuscript is typed strictly with the following rules:

a. The title, short and clear, written in English. The title length does not exceed 20 words.

b. Authors, listed without mention of title or degree, under the name including the affiliation and complete address, and email of the corresponding author. The author's name, which consists of one word, must be repeated twice for first and last names. To author with names of more than two words, the author's last name consists of only one word, the rest is written as the first name.

c. Abstract, written in English which is a summary of the article. The abstract is created in one paragraph and a maximum of 250 words with Book Antiqua font $9 \mathrm{pt}$, single column, and space 1 . Points that must be listed in the abstract include the research objectives, methods, results, conclusions, and keywords. The number of keywords is between three and five keywords.

d. Introduction, contain background, reasons for the importance of underlying research or hypotheses, general approaches and objectives of the research and relevant literature review. The number of paragraphs not restricted but the contents must include background, objectives, positions on previous research, as well as the novelty of the research. The little theoretical basis which indirectly related to the contents of the article could be included without sub-chapters required. Citation is written in occurrence number on the manuscript (Vancouver style).

e. Methodology, Research method consists of 2 sub-chapters including materials and methods. If data analysis is specific, or the way of analysis is novel, then data analysis subchapter could be added. The sub-chapters are written without numbering or bullet.

f. Results and Discussion, at least contain three subjects (1) description of results, (2) interpretation or explanation of results, and (3) comparative of results with previous studies results. If the subchapters very length could be made sub-sub-chapters with Arabic numbering. Description of the results can be in the form of tables and figures with a serial number (Table uses a sequence of Roman numerals and placed at the top, while figures using Arabic numeric sequence and placed in the below).

g. Conclusion, made in a single paragraph without the citation contains the final conclusion and suggestions for advanced research.

h. References, a list of recently selected topics is published last five years (the minimum percentage and a minimum number of references are different for each type of manuscript). The bibliography is written in chronological order with the serial number (Vancouver style) and suggested using a reference management application such as EndNote, Mendeley, Zotero, and other applications.

6. Authors whose manuscripts are published are free of charge for both Publication cost and article processing charge.

7. Authors will get full access to the article published on e-journal of Universitas Muhammadiyah Palangkaraya at the website http://journal.umpalangkaraya.ac.id/index.php/bjop. 


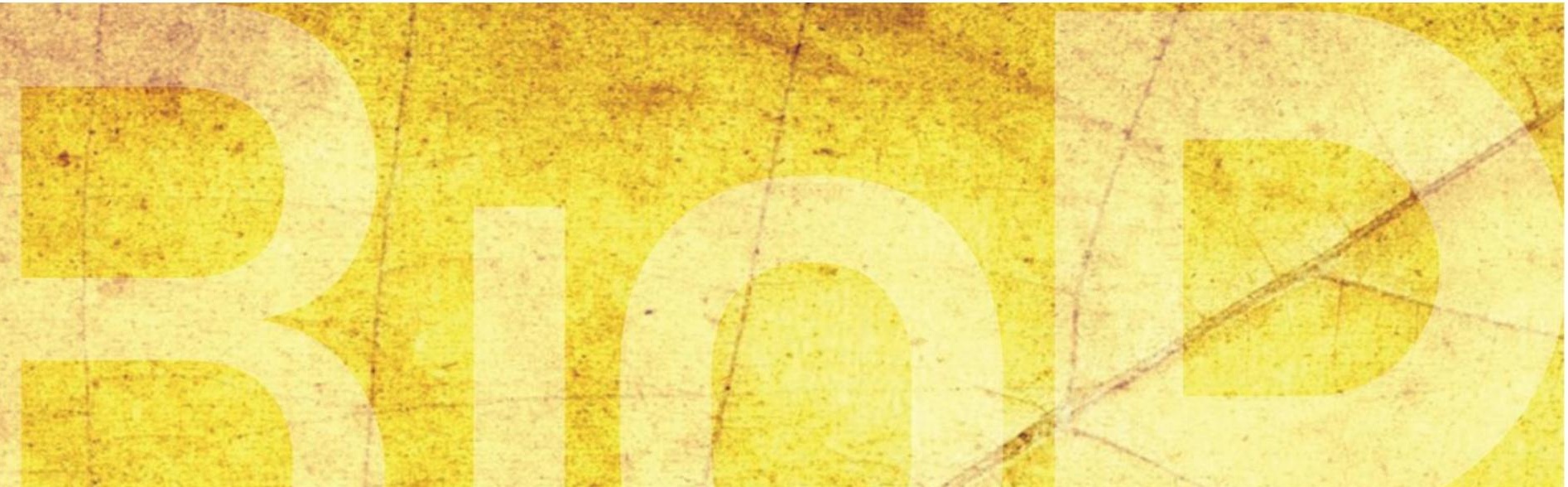

\section{Borneo Journal of PHARMACY}

Volume 4 Issue 4 November 2021

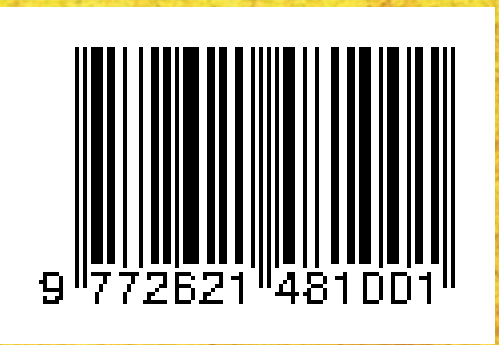

